\title{
INTERPRETATION OF CONTRACTS AND "COMMERCIAL COMMON SENSE": DO NOT OVERPLAY THIS USEFUL CRITERION
}

\author{
Neil Andrews, \\ University of Cambridge
}

"We are there to oil the wheels of commerce, not to put spanners in the works, or even grit in the oil." 1

\section{Introduction}

The broad notion of "commercial common sense" is prominent in the modern law governing the interpretation of written contracts. For example, in Prenn $v$ Simmonds (1971) ${ }^{2}$ Lord Wilberforce said that a suggested interpretation could be tested by considering whether it would "correspond with commercial good sense." Lord Steyn said in Mannai Investment Co v Eagle Star Life Assurance (1997): "Words are ...interpreted in the way in which a reasonable commercial person would construe them." In the "Rainy Sky" case (2011) the Supreme Court held: "If there are two possible constructions, the court is entitled to prefer the construction which is consistent with business common sense and to reject the other." Furthermore, Lord Neuberger in Arnold v Britton (2015) 5 placed "commercial common sense" within the list of relevant factors to be applied during the process of interpretation (see Section II for the full quotation). Most people will instinctively nod approval to these important judicial statements. But to what, precisely, are they assenting? It is the aim of this paper to explain both the growth and versatile operation of commercial common sense ${ }^{6}$ (CCS) within the law concerning interpretation and to take stock of the concerns expressed by some judges that this notion should not be overplayed.

\footnotetext{
1 Sir Robert Goff, “Commercial contracts and the Commercial Court” [1984] L.M.C.L.Q. 382, 391.

2 [1971] 1 W.L.R. 1381, 1389, H.L.

3 [1997] A.C. 749, 771, H.L.

${ }^{4}$ Rainy Sky SA v Kookmin Bank [2011] UKSC 50; [2011] 1 W.L.R. 2900 at [21], per Lord Clarke.

${ }^{5}$ Arnold v Britton [2015] UKSC 36; [2015] A.C. 1619 at [15].

${ }^{6}$ No distinction is drawn between "commercial" and "business" common sense.
} 
There is more than one idea at play here. Thus commercial common sense is a factor which is variously described as requiring the court to produce a "commercial solution" "commercial result" 8 or a "commercially sensible result", to promote the parties' "commercial aims and objectives", ${ }^{9}$ to display "commerciality", 10 to take account of "the commercialities", ${ }^{11}$ to have regard to "commercial and factual background known to both parties", ${ }^{12}$ to consider the perspective of a "reasonable commercial reader", ${ }^{13}$ to prefer an interpretation which has a "greater degree of common sense"14 than another, and to avoid a result which is "unworkable"15 or (as we shall see extensively in Section IV) "obviously absurd". ${ }^{16}$

On closer inspection, this notion of "commerciality" covers at least six different points: (1) commercial documents are to be read from the perspective of commercial users; in particular, the commercial reader abhors pedantry, including excessive technicality or semantic logic; (2) the court should avoid frustrating the parties' commercial object or purpose revealed by the contractual text and its factual matrix; (3) the adjudicator must understand the trade practices and market assumptions within the relevant contractual pigeon-hole; (4) inapt words can be overridden when manifestly inconsistent with business common sense (this overlaps with both "corrective construction", see nn. 41-47, and Rectification, nn. 38-40); (5) absurd constructions are to be avoided; (6) commercial common sense can be used as a compass to point the way when the court is confronted by rival meanings (points (1) to (6) are developed in Section III below).

In Section II, we begin by noting the central features of the English rules governing interpretation of written contracts. ${ }^{17}$ Beatson L.J. in the Globe Motors case (2016) ${ }^{18}$ conducted a thorough review of the modern English authorities and Christopher Clarke L.J.'s earlier

${ }^{7}$ Law Land Company Ltd v Consumers' Association Ltd [1980] 2 E.G.L.R. 109, per Brightman L.J.; Jackson v Dear [2012] EWHC 2060 (Ch) at [40] (vii), per Briggs J. (reversed, but not on this point, [2013] EWCA Civ 89; [2014] 1 B.C.L.C. 186).

${ }^{8}$ Re Golden Key [2009] EWCA Civ 636 at [28], per Arden L.J.

9 BSEN Ltd (BVI) v Micado Shipping Ltd (Malta) ("The Seaflower") [2001] C.L.C. 421 at [82], per Jonathan Parker L.J.

${ }^{10}$ [2009] EWCA Civ 636 at [28], per Arden L.J.

${ }^{11}$ Hut Group Ltd v Nobahar-Cookson [2016] EWCA Civ 128 at [30], per Briggs L.J.

12 Arnold v Britton [2015] UKSC 36; [2015] A.C. 1619 at [21], per Lord Neuberger; Ravennavi SpA v New Century Shipbuilding Co Ltd [2007] EWCA Civ 58; [2007] 2 All E.R. (Comm.) 756; [2007] 2 Lloyd's Rep. 24; [2007] 1 C.L.C. 176 at [12], per Moore-Bick L.J.

${ }^{13}$ Mannai Investment Co v Eagle Star Life Assurance [1997] A.C. 749, 771, H.L., per Lord Steyn.

${ }^{14}$ LB Re Financing No. 3 Ltd v Excalibur Funding No. 1 plc [2011] EWHC 2111 (Ch) at [46], per Briggs J.

${ }_{15}$ Unite the Union v Liverpool Victoria Banking Services Ltd [2015] EWCA Civ 285 at [34] and [35], per Christopher Clarke L.J.

16 Torvald Klaveness A/S v Arni Maritime Corporation [1994] 1 W.L.R. 1465, 1473, H.L, per Lord Mustill.

17 R. Calnan, Principles of Contractual Interpretation (Oxford: Oxford University Press, 2014); Lewison on the Interpretation of Contracts, 6th ed. (London: Sweet \& Maxwell, 2015); G. McMeel, The Construction of Contracts: Interpretation, Implication and Rectification, 2nd ed. (Oxford: Oxford University Press, 2011); C. Mitchell, Interpretation of Contracts, 2nd ed. (Abingdon, Oxon: Routledge-Cavendish, forthcoming, 2017); from an Australian perspective, J.W. Carter The Construction of Commercial Contracts (Oxford: Hart Publishing, 2013).

${ }^{18}$ Globe Motors Inc v TRW Lucas Varity Electric Steering Ltd [2016] EWCA Civ 396; [2017] 1 All E.R. (Comm) 601 at [56] ff. 
encapsulation in Wood v Sureterm Direct Ltd \& Capita Insurance Services Ltd (2015) has been described as "lucid" and "concise". ${ }^{19}$ The position in Australia, ${ }^{20}$ Canada, ${ }^{21}$ Hong Kong, ${ }^{22}$ New Zealand, ${ }^{23}$ Singapore $^{24}$ and the USA $^{25}$ would require extensive further discussion. Section III contains analysis of judicial statements concerning commercial common sense (CCS). Those statements reveal three main points, which will be developed in Sections IV to VI: (1) CCS not only precludes "absurdity" (Section IV) but (2) it enables the court to select the superior interpretation, when there are rival meanings available (Section V); however, (3) there are four dangers, or causes for concern, which have emerged within the cases (Section VI). First, "commercial common sense" can be used as camouflage for partisan arguments which are really pleas for advantage not truly supported by the document. This card is too often played, sometimes by both sides. Judges should not be beguiled by forensic rhetoric. Secondly, judges should know when they are venturing perilously beyond their mercantile comfort-zone: they should not pretend to greater experience than they in fact possess. Thirdly, commercial common sense should not become a pretext for rewriting the text in order to "improve" it. Fourthly, a transaction's curious or tough wording ${ }^{26}$ might be the direct product of close negotiation. That possibility looms large under the English

${ }_{19}$ In Mutual Energy Ltd $v$ Starr Underwriting Agents Ltd, Travellers Syndicate Management Ltd [2016] EWHC 590 (TCC); [2016] B.L.R. 312; 165 Con. L.R. 220 at [14], per Coulson J., citing Wood v Sureterm Direct Ltd E Capita Insurance Services Ltd [2015] EWCA Civ 839 at [28] to [31], per Christopher Clarke L.J. (affmd. [2017] UKSC 24; [2017] 2 W.L.R. 1095) (on the latter case, see text at nn. 203-204 below).

${ }^{20}$ Electricity Generation Corpn v Woodside Energy Ltd [2014] HCA 7; (2014) 251 C.L.R. 640; 306 A.L.R. 25; 88 A.L.J.R. 447 at [35]; Maintech Services Pty Ltd v Stein Heurtey SA [2014] NSWCA 184; (2014) 89 N.S.W.L.R. 633, notably, [69], [71], [82], [84], [105], [106]; [115] to [121], per Leeming J.A.; Mount Bruce Mining Pty Limited v Wright Prospecting Pty Limited [2015] HCA 37 at [51] and [52], [107] to [113], [118] to [123]; J.W. Carter, "Context and Literalism in Construction" (2014) 31 J.C.L. 100; J.W. Carter, The Construction of Commercial Contracts (Oxford: Hart Publishing, 2012);

${ }^{21}$ Canada: Sattva Capital Corp v Creston Mining Corp [2014] SCC 53, [2014] 2 S.C.R. 633 at [42] to [61]; noted S. Waddams (2015) 131 L.Q.R. 48-52; G.R. Hall, Canadian Contractual Interpretation Law, 2nd ed. (Markham, Ontario: Lexis Nexis, 2012).

${ }_{22}^{2}$ Hong Kong: Fully Profit (Asia) Ltd v Secretary for Justice [2013] HKCFA 40; [2013] 6 H.K.C. 374; (2013) 16 H.K.C.F.A.R. 351 at [15]; Jumbo King Ltd v Faithful Properties Ltd [1999] HKCFA 38; [1999] 3 H.K.L.R.D. 757; (1999) 2 H.K.C.F.A.R. 279; [1999] 4 H.K.C. 707, at [59], per Lord Hoffmann N.P.J.; Neil Andrews and Fan Yang, Contract Law in Hong Kong (HK University Press, 2016), chapter 9.

${ }^{23}$ New Zealand: Firm PI 1 Ltd v Zurich Australian Insurance Ltd [2014] NZSC 147; [2015] 1 N.Z.L.R. 432, at [88] to [93] (noted R. Havelock [2015] L.M.C.L.Q. 174-179); and see D. McLaughlan, "Contract Interpretation in the Supreme Court-Easy Case, Hard Law?" (2010) N.Z.B.L.Q. 229 at 236-8.

${ }^{24}$ Singapore: Hewlett-Packard Singapore (Sales) Pte Ltd v Chin Shu Hwa Corinna [2016] SGCA 19 at [54] to [56]; Goh Yihan, "The New Contractual Interpretation in Singapore" [2013] Sing. J.L.S. 301.

${ }^{25}$ USA: S.J. Burton, Elements of Contract Interpretation (New York: Oxford University Press, 2009); Alan Schwartz and Robert E. Scott, “Contract Interpretation Redux" (2010) 119 Yale L.J. 926; Ronald J. Gilson, Charles F. Sabel, Robert E. Scott, “Text and Context: Contract Interpretation as Contract Design” (2014) 100 Cornell L. Rev. 23; Robert E. Scott, "Text versus Context: The Failure of the Unitary Law of Contract Interpretation”, in F.H. Buckley (ed.), The American Illness: Essays on the Rule of Law (New Haven: Yale University Press, 2013).

${ }^{26}$ Skanska Rashleigh Weatherfoil Ltd v Somerfield Stores Ltd [2006] EWCA Civ 1732; [2007] C.I.L.L. 2449 at [21], per Neuberger L.J. 
arrangements because courts cannot lift the lid on negotiations (text at nn. 35-36 below). ${ }^{27}$ In the face of that possibility, judicial humility and restraint must be shown.

\section{Interpretation: the Modern English System}

In his latest $\mathrm{t}^{28}$ "restatement" of this topic, Lord Neuberger in Arnold $v$ Britton (2015) ${ }^{29}$ placed CCS fifth in his list of factors which supplement the major criterion of "objectivity":

"When interpreting a written contract, the court is concerned to identify... 'what a reasonable person having all the background knowledge which would have been available to the parties would have understood them to be using the language in the contract to mean'...And it does so by focussing on the meaning of the relevant words...in their documentary, factual and commercial context. That meaning has to be assessed in the light of (i) the natural and ordinary meaning of the clause, (ii) any other relevant provisions of the [document], (iii) the overall purpose of the clause and the [document], (iv) the facts and circumstances known or assumed by the parties at the time that the document was executed, and (v) commercial common sense, but (vi) disregarding subjective evidence of any party's intentions."

The Common Law system of interpretation starts and ends ${ }^{30}$ with "objectivity", ${ }^{31}$ which is one of only a handful of leading principles in English contract law. ${ }^{32}$ Investors Compensation Scheme Ltd v West Bromwich Building Society (No. 1) ("ICS") (1998) $)^{33}$ requires the court to adopt the perspective of an objective reader, independently of each party's particular perspective, and so without reference to (1) each party's declarations of subjective intent, ${ }^{34}$ (2) the parties' actual negotiations ${ }^{35}$ (unless they disclose objective background facts) ${ }^{36}$ or (3) their post-formation dealings. ${ }^{37}$

\footnotetext{
27 Prenn v Simmonds [1971] 1 W.L.R. 1381, 1384-5, H.L., per Lord Wilberforce; Investors Compensation Scheme Ltd v West Bromwich Building Society (No 1) [1998] 1 W.L.R. 896, 913, H.L., per Lord Hoffmann; Chartbrook Ltd v Persimmon Homes Ltd [2009] UKHL 38; [2009] 1 A.C. 1101 at [28] to [47], per Lord Hoffmann.

${ }^{28}$ Earlier, Marley $v$ Rawlings [2014] UKSC 2; [2015] A.C. 129 at [19].

${ }^{29}$ Arnold $v$ Britton [2015] UKSC 36; [2015] A.C. 1619 at [15].

${ }^{30}$ What we call the beginning is often the end

And to make an end is to make a beginning.

The end is where we start from. (T.S. Eliot, Little Gidding).

${ }^{31}$ McCutcheon v David MacBrayne Ltd [1964] 1 W.L.R. 125, H.L., per Lord Reid; G. Leggatt, "Making Sense of Contracts: the Rational Choice Theory" (2015) 131 L.Q.R. 454.

32 Andrew Burrows, A Restatement of the English Law of Contract (Oxford: Oxford University Press, 2016), section 5 ("freedom of contract"), sections 6(2) and 14(1) (objectivity); Neil Andrews, Contract Rules; Decoding English Law (Cambridge: Intersentia Publishing, 2016), Articles 1 (freedom of contract), 2 (objectivity), 3 (binding force of agreement), 4 (estoppel), 5 (good faith and fair dealing: a latent principle).

${ }^{33}$ Investors Compensation Scheme Ltd $v$ West Bromwich Building Society (No. 1) [1998] 1 W.L.R. 896, 912-13, H.L.

34 Investors Compensation Scheme Ltd $v$ West Bromwich Building Society (No. 1) [1998] 1 W.L.R. 896, 913, H.L., per Lord Hoffmann.

${ }^{35}$ Chartbrook Ltd v Persimmon Homes Ltd [2009] UKHL 38; [2009] 1 A.C. 1101 at [28] to [47], per Lord Hoffmann.

${ }^{36}$ Oceanbulk Shipping and Trading SA v TMT Asia Ltd [2010] UKSC 44; [2011] 1 A.C. 662; Paul S. Davies [2011] C.L.J. 247.

${ }_{37}$ Whitworth Street Estates (Manchester) Ltd v James Miller E Partners Ltd [1970] A.C. 583, 603, H.L., per Lord Reid.
} 
As for (2) (the bar on evidence of the parties' actual negotiations), the equitable doctrine of Rectification allows a party to place in evidence drafts or other negotiations in order to cure a mismatch between the parties' pre-formation settled intention and the wording adopted in the text of their final agreement ${ }^{38}$ (objectivity also applies to determine whether there was a prior common intention). ${ }^{39}$ Rectification can also be invoked to reflect one party's mistaken assumption concerning the contents of the proposed contract if the other party in bad faith had failed to point out that mistake before formation. ${ }^{40}$ But, even without resort to Rectification, the ICS (1998) $)^{41}$ and Chartbrook (2009) ${ }^{42}$ cases confirm that the process of construction requires the courts to reconstruct phrases if it is obvious that something has gone wrong in the contractual formulation and it is also clear how the textual defect is to be put right (so-called "corrective construction"). However, a clear case must be established because Lord Hoffmann in the ICS case noted the presumption against linguistic mistakes. ${ }^{43}$ This "something has gone wrong" (patent defect/obvious fix) rule ${ }^{44}$ has been applied many times. ${ }^{45}$ But it is controversial, ${ }^{46}$ not least because it substantially duplicates the traditional function of Rectification. ${ }^{47}$

Although the main focus of this discussion is written contracts, it should be noted ${ }^{48}$ that similar, if not identical, principles apply to the construction of other legal documents, such as patents, ${ }^{49}$ planning agreements, ${ }^{50}$ trust deeds, ${ }^{51}$ and unilateral notices. ${ }^{52}$

\footnotetext{
${ }^{38}$ Daventry District Council v Daventry E District Housing Ltd [2011] EWCA Civ 1153; [2012] 1 W.L.R. 1333 at [227], per Etherton L.J.

${ }^{39}$ [2011] EWCA Civ 1153; [2012] 1 W.L.R. 1333 at [54], [55], [78] to [80], [159], [179] to [181], [195] to [197], per Lord Neuberger M.R.; Chartbrook Ltd v Persimmon Homes Ltd [2009] UKHL 38; [2009] 1 A.C. 1101 at [60] to [65]. ${ }^{40}$ George Wimpey UK Ltd v VI Components Ltd [2005] EWCA Civ 77; [2005] B.L.R. 135; 103 Con L.R. 67; [2005] 2 P \& CR DG5; D. McLauchlan, “The "Drastic" Remedy of Rectification for Unilateral Mistake" (2008) 124 L.Q.R. 608-40.

${ }^{41}$ Investors Compensation Scheme Ltd v West Bromwich Building Society (No. 1) [1998] 1 W.L.R. 896, 912-3, H.L., propositions (iv) and (v).

${ }^{42}$ Chartbrook Ltd v Persimmon Homes Ltd [2009] UKHL 38; [2009] 1 A.C. 1101 at [22] to [25], per Lord Hoffmann.

43 [1998] 1 W.L.R. 896, 913, H.L. (rule (5)).

${ }^{4}$ E.g., A.S. Burrows, "Construction and Rectification”, in A.S. Burrows and E. Peel (eds.), Contract Terms (Oxford: Oxford University Press, 2007), 77; R. Buxton, "Construction' and Rectification After Chartbrook" [2010] C.L.J. 253.

45 E.g., Chartbrook Ltd v Persimmon Homes Ltd [2009] UKHL 38; [2009] 1 A.C. 1101 (noted D. McLaughlan (2010) 126 L.Q.R. 8-14); Pink Floyd Music Ltd v EMI Records Ltd [2010] EWCA Civ 1429; [2011] 1 W.L.R. 770 Caresse Navigation Ltd v Zurich Assurances Maroc [2014] EWCA Civ 1366; [2015] Q.B. 366 (noted F. Chan (2015) 131 L.Q.R. 372).

${ }^{46}$ In Marley v Rawlings [2014] UKSC 2; [2015] A.C. 129 at [37] and [39], Lord Neuberger declared "controversial" the invitation to engage in extensive "corrective construction" made by Lord Hoffmann in Chartbrook Ltd $v$ Persimmon Homes Ltd [2009] UKHL 38; [2009] 1 A.C. 1101 at [25] ("there is not, so to speak, a limit to the amount of red ink or verbal rearrangement or correction which the court is allowed").

47 R. Calnan, Principles of Contractual Interpretation (Oxford: Oxford University Press, 2013), 7.134: "it does look very much like a form of summary rectification ('rectification lite')."

${ }^{48}$ Trump International Golf Club Scotland v Scottish Ministers [2015] UKSC 74; [2015] 1 WLR 85 at [33], per Lord Hodge: "there has been a harmonisation of the interpretation of contracts, unilateral notices, patents and also testamentary documents".

${ }^{49}$ Kirin-Amgen Inc v Hoechst Marion Roussel Ltd [2004] UKHL 46; [2005] 1 All ER 667; [2005] R.P.C. 9, at [32].

${ }^{50}$ Trump International Golf Club Scotland $v$ Scottish Ministers [2015] UKSC 74; [2015] 1 WLR 85; R. (on the application of Robert Hitchins Ltd) $v$ Worcestershire CC [2015] EWCA Civ 1060; [2016] J.P.L. 373 at [28].

${ }^{51}$ BNY Mellon Corporate Trustee Services Ltd v LBG Capital No.1 plc [2015] EWCA Civ 1257; [2016] 2 B.C.L.C. 163, at [80] to [90] (affmd., but without deciding this point, [2016] UKSC 29; [2016] 2 Lloyd's Rep. 119).
} 


\section{Six Manifestations of "Commercial Common Sense"}

CCS began its resurgence in Lord Wilberforce's speech in Prenn v Simmonds (1971), ${ }^{53}$ where he rejected the losing party's rival interpretation in these terms: "[that suggested] construction does not fit in any way the aim of the agreement, or correspond with commercial good sense, nor is it, even linguistically, acceptable." Lord Wilberforce returned to these issues in his speech in the Reardon case (1977). ${ }^{54}$ As we shall see in this Section, the root idea of a business-like approach to interpretation has produced six types of emphasis: (1) anti-pedantry; (2) regard for a transaction's commercial purpose; (3) consideration of trade practices and market assumptions within the relevant contractual pigeon-hole; (4) overcoming drafting slips; (5) avoiding absurdity; (6) and, most significantly, commercial common sense can be used as a compass to guide the court when it encounters rival meanings.

\section{Anti-pedantry and anti-literalism: contracts are written to be read by businessmen and not monopolised by lawyers}

Commercial common sense requires the judge to consider how the document would be read by businessmen positioned in the relevant market or commercial context. In "The Starsin" (2003) Lord Bingham noted:55 "business sense is that which businessmen, in the course of their ordinary dealings, would give the document." Judges have protested at over-refined and nit-picking semantic analysis, because this distracts from the task of viewing the relevant phrase within the whole document and against its commercial background. ${ }^{56}$ There is also the potential embarrassment that a lower court's confident reliance on grammatical rules, such as the nature of a particular use of the past tense and whether it lacks any "continuous" connotation, might be convincingly falsified on appeal. ${ }^{57}$ Lord Steyn said in Mannai Investment Co v Eagle Star Life Assurance (1997): 58 "Words are ...interpreted in the way in which a reasonable commercial person would construe them. And the standard of the reasonable commercial person is hostile to technical interpretations and undue emphasis on niceties of language." Jonathan Parker L.J. said in "The Seaflower" (2001) that commercial common sense is an antidote to "minute textual examination and analysis". ${ }^{59}$ Another protest against over-

\footnotetext{
52 Mannai Investment Co Ltd v Eagle Star Life Assurance Co Ltd [1997] AC 749, HL.

53 Prenn $v$ Simmonds [1971] 1 W.L.R. 1381, 1389, H.L.

${ }^{54}$ Reardon Smith Line Ltd v Yngvar Hansen-Tangen ("The Diana Prosperity") [1976] 1 W.L.R. 989, 995-997, H.L; on which Lord Neuberger, "The impact of pre-and post-contractual conduct on contractual interpretation" (Banking Services and Finance Law Association Conference, Queenstown, 2014) at [18] (<https://www.supremecourt.uk/docs/speech-140811.pdf> last accessed 2 September, 2016).

${ }^{55}$ Homburg Houtimport BV v Agrosin Private Ltd ("The Starsin”) [2003] UKHL 12; [2004] 1 A.C. 715 at [10].

56 Ravennavi SpA v New Century Shipbuilding Co Ltd [2007] EWCA Civ 58; [2007] 2 All E.R. (Comm.) 756; [2007] 2 Lloyd's Rep. 24; [2007] 1 C.L.C. 176 at [12], per Moore-Bick L.J.

57 E.g., Napier Park European Credit Opportunities Fund Ltd v Harbourmaster Pro-Rata CLO 2 BV [2014] EWHC 1083 (Ch) at [42], per Sir Terence Etherton C.; reversed [2014] EWCA Civ 984 at [27], per Lewison L.J.

58 [1997] A.C. 749, 771, H.L.

${ }^{59}$ BSEN Ltd (BVI) v Micado Shipping Ltd (Malta) ("The Seaflower") [2001] C.L.C. 421 at [82], per Jonathan Parker L.J.
} 
refined semantic analysis is Lord Collins' remark in Re Sigma (2009):60 "This is one of those too frequent cases where a document has been subjected to the type of textual analysis more appropriate to the interpretation of tax legislation which has been the subject of detailed scrutiny at all committee stages than to an instrument securing commercial obligations." In the Hong Kong Court of Final Appeal, in Jumbo King Ltd v Faithful Properties Ltd (1999), Lord Hoffmann said pithily: ${ }^{61}$ "the overriding objective in construction is to give effect to what a reasonable person rather than a pedantic lawyer would have understood the parties to mean." More recently, Beatson L.J. in the Globe Motors case (2016) ${ }^{62}$ approved this elegant statement by Sir Thomas Bingham M.R.63

“...To seek to construe any instrument in ignorance or disregard of the circumstances which gave rise to it or the situation in which it is expected to take effect is in my view pedantic, sterile and productive of error. ...To my mind construction is a composite exercise, neither uncompromisingly literal nor unswervingly purposive: the instrument must speak for itself, but it must do so in situ and not be transported to the laboratory for microscopic analysis."

Furthermore, some texts are simply unfit to be placed under the semantic microscope. As Lord Bingham said in "The Starsin" (2003):64 "to seek perfect consistency and economy of draftsmanship in a complex form of contract which has evolved over many years is to pursue a chimera... If an obviously inappropriate form is used, its language must be adapted to apply to the particular case."

This emphasis upon adopting a business-like approach to reading commercial agreements is no novelty. In McCowan $v$ Baine (1893), ${ }^{65}$ the House of Lords held, construing an insurance contract, that a maritime collision between one vessel and "The Niobe" extended to the present case where a vessel collided with a tug pulling "The Niobe" (Lord Bramwell dissented) ${ }^{66}$ In the majority, the Earl of Selborne referred ${ }^{67}$ to the need to avoid "extreme literalism". ${ }^{68}$ Lord Morris construed the contract as "as an insurance against...liability for payment by collision to be incurred by 'The Niobe' while in tow.... I consider the tug part of the apparatus for moving the ship..., and that a collision by the tug while so towing...was a collision of 'The Niobe' within the meaning of the...policy." Similarly, in the Southland Frozen Meat case (1898), Lord Herschell said that written provisions "must be construed in a business fashion, and that the words must not be applied to everything that might be said to come within a possible dictionary use of them, but must be interpreted in the way in which

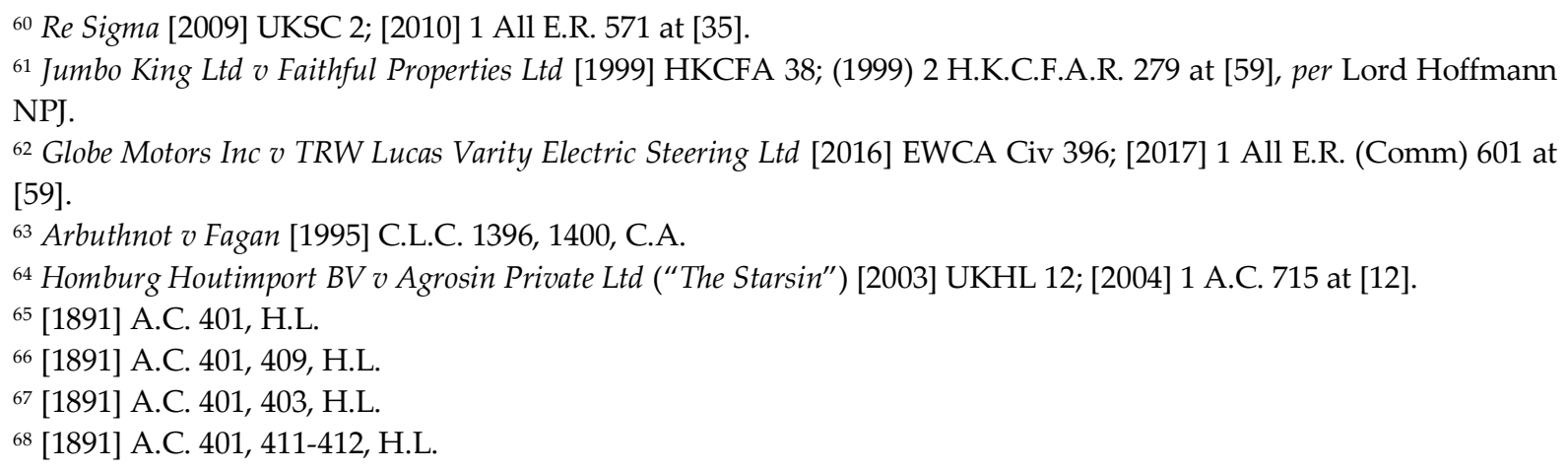


business men would interpret them, when used in relation to a business matter of this description." 69

\section{The transaction's commercial purpose or object}

The document's commercial "purpose" or "object" can be used, according to Lord Herschell L.C. ${ }^{70}$ in Glynn $v$ Margetson $\&$ Co (1893), "in limiting the general words used" and, according to Lord Halsbury, ${ }^{71}$ to "reject words, indeed whole provisions, if they are inconsistent with what one assumes to be the main purpose of the contract." In this case the House of Lords held that the written terms of a contract for carriage of oranges from Malaga to Liverpool did not entitle the shipowner to make deviations to remoter ports in the Mediterranean, because the consequent delay would obviously imperil a perishable cargo. This was so even though words had been introduced into the contract which appeared to grant the shipowner free rein to adopt an erratic route. Lord Herschell L.C. said that the contract needed to be construed "in a business sense", ${ }^{72}$ and Lord Halsbury said: "[a person construing the contract] must consider whether mercantile men when they do business in this form do not recollect that a business sense will be given to business documents."73 This was echoed by Lord Wilberforce in Prenn $v$ Simmonds (1971): $:{ }^{74}$ "the commercial, or business object, of the transaction, objectively ascertained, may be a surrounding fact... And if it can be shown that one interpretation completely frustrates that object, to the extent of rendering the contract futile, that may be a strong argument for an alternative interpretation, if that can reasonably be found."

The document's "purpose", "object", "aim",75 or "intended commercial result",76 must be divined by reference to the contested portion of the agreement, the whole text, and relevant background facts and context. ${ }^{77}$ The "purpose" or "object" should not be the judge's personal fantasy of how that type of transaction might ideally be reconstructed. As Lord Grabiner notes: ${ }^{.8}$ "It is critically important that the 'commercial purpose' of the transaction is derived from the contract as a whole and from an accurate understanding of the way in which the various provisions interact." And Lewison (2015) $)^{79}$ comments that courts must not adopt "a preconceived idea of what contracts of that description generally seek to achieve"

\footnotetext{
${ }^{69}$ Southland Frozen Meat and Produce Export Company Ltd v Nelson Brothers Ltd [1898] A.C. 442, 444, P.C., per Lord Herschell.

70 [1893] A.C. 351, 355, H.L.

71 [1893] A.C. 351, 357, H.L.

72 [1893] A.C. 351, 356, H.L.

73 [1893] A.C. 351, 356, H.L.

${ }^{74}$ [1971] 1 W.L.R. 1381, 1385, H.L.

75 Prenn v Simmonds [1971] 1 W.L.R. 1381, 1389, H.L.

${ }^{76}$ Re Golden Key Ltd [2009] EWCA Civ 636 at [28], per Arden L.J.

77 Bank of Nova Scotia v Hellenic Mutual War Risks Association (Bermuda) Ltd ("The Good Luck"): [1990] Q.B. 818, 870,

C.A. (reversed, but not on this point, [1992] 1 A.C. 233, H.L.).

${ }^{78}$ Lord Grabiner, "The Iterative Process of Contractual Interpretation" (2012) 128 L.Q.R. 41, 46.

${ }^{79}$ Lewison on the Interpretation of Contracts, 6th ed. (London: Sweet \& Maxwell, 2015), 2.08 at page 69.
} 
and then "force the words of the particular contract to fit that preconception". As Lord Wilberforce explained in the Reardon case (1976): 80

"the court should know the commercial purpose of the contract and this in turn presupposes knowledge of the genesis of the transaction, the background, the context, the market in which the parties are operating...[When] one is speaking of aim, or object, or commercial purpose, one is speaking objectively of what reasonable persons would have in mind in the situation of the parties..."

\section{Trade practices and market assumptions within the relevant contractual pigeon-hole}

The adjudicator must be made aware of relevant commercial usages, which might vary from locality to locality. For example, in Jacobs $v$ Scott $\mathcal{E}$ Co $(1899)^{81}$ the House of Lords held that hay imported from Canada to Glasgow had to contain no more than 20 per cent clover and that the supplier, although not based in Scotland, was subject to that implicit specification. A higher percentage was tolerated in the other main UK hay markets, namely London and Bristol. The decision illustrates the variability of market standards within different parts of the UK.

Other usages might be "market-wide". And so in Tidal Energy Ltd $v$ Bank of Scotland plc (2014) the Court of Appeal held that, when construing the contractual words "to the beneficiary", it was legitimate to impute to a bank customer the fact that bank transfers by the CHAPS system (clearing house automated payment system) do not require the transferor's bank to check the name of the intended transferee. ${ }^{82}$ Lord Dyson M.R., with whom Tomlinson L.J. agreed, said: ${ }^{3}$ " $\ldots$ a customer who uses CHAPS is taken to contract on the basis of the banking practice that governs CHAPS transactions. On the evidence which the judge accepted, there is a clear and settled practice that the receiving bank in a CHAPS transaction does not check the beneficiary's name for correspondence with the other identifiers." Lord Dyson M.R. went on ${ }^{84}$ to consider numerous points of "business common sense" which supported his conclusion that a bank is not under an obligation to check the accuracy of the transferor's naming of the intended recipient of the funds. These comments are a convincing demonstration of the importance and analytical power of opening up issues of interpretation to full examination of the "commercial matrix", 85 that is, the exigencies and realities within which the relevant transaction is placed.

Another example of the court bringing to bear its informed knowledge of the nature of a transaction in a particular market is PST Energy 7 Shipping LLC v OW Bunker Malta Ltd ("The

\footnotetext{
${ }^{80}$ Reardon Smith Line Ltd v Yngvar Hansen-Tangen ("The Diana Prosperity") [1976] 1 W.L.R. 989, 995-6, H.L.

81 (1899) 2 F (HL) 70.

82 [2014] EWCA Civ 1107; [2015] 2 All E.R. 15 (noted, D. McLaughlan, [2015] L.M.C.L.Q. 406, 408-409).

83 [2014] EWCA Civ 1107; [2015] 2 All E.R. 15 at [59].

84 [2014] EWCA Civ 1107; [2015] 2 All E.R. 15 at [62].

${ }^{85}$ Globe Motors Inc $v$ TRW Lucas Varity Electric Steering Ltd [2016] EWCA Civ 396; [2017] 1 All E.R. (Comm) 601 at [75], per Beatson L.J.
} 
Res Cogitans") (2016). ${ }^{86}$ Here the Supreme Court held that a contract for the supply of bunkers (ship fuel) required the recipient to pay for fuel in fact used for ship propulsion even though, for technical reasons, the transaction fell outside the sale of goods legislation. ${ }^{87}$ In the following passage, Lord Mance in the Supreme Court began by noting the wording: ${ }^{8}$ "After going on to provide that the buyer 'shall not be entitled to use the bunkers', the terms introduce the qualification 'other than for the propulsion of the vessel'." He then explained the commercial context: ${ }^{89}$

"The qualification clearly reflects a reality. Bunker suppliers know that bunkers are for use. If they grant relatively long credit periods combined with a reservation of title pending payment in full, it is unsurprising that they do so combined with an express qualification authorising use in propulsion, since standard terms prohibiting any use would be uncommercial or in practice, no doubt, simply ignored....[Those terms] - together with an admissible modicum of commercial awareness on the court's part about how ships operate (and in particular how owners strive to keep them operating) and about the value of credit and the likelihood that full advantage of it will be taken - all point in one direction. They demonstrate that the liberty to use the bunkers for propulsion prior to payment is a vital and essential feature of the bunker supply business."

As for the contention that the transaction was labelled for the "sale" of goods, and could not, therefore, be given effect outside the scheme of the Sale of Goods legislation, in the Court of Appeal Moore-Bick L.J. persuasively dismissed this argument as follows: ${ }^{90}$

"The question is simply whether [in the language of the transaction] the characterisation by the parties of the contract as one of sale adequately reflects the substance of the obligations to which it gives rise. ...[It] is no part of the court's function to shoehorn their contract into a category to which it does not properly belong in order to impose on them consequences which they did not intend."

The Court of Appeal then analysed the transaction as essentially hybrid. Although not a sale stricto sensu, it did give rise to a duty to pay for bunkers actually consumed, as well as those left unconsumed. This decision was upheld by the Supreme Court, as mentioned in the text above.

Of course, sometimes the court's judgment will itself directly ${ }^{91}$ prescribe or adjust the relevant market practice or assumption, for example when the court authoritatively

\footnotetext{
${ }^{86}$ [2016] UKSC 23; A.C. 1034, notably at [28] to [31], [37], [39], [59], per Lord Mance.

87 The supplier had not undertaken "to transfer title" in the goods under s. 2(1), Sale of Goods Act 1979.

88 [2016] UKSC 23; [2016] A.C. 1034 at [26], per Lord Mance.

89 [2016] UKSC 23; [2016] A.C. 1034 at [27], per Lord Mance.

90 [2015] EWCA Civ 1058; [2016] A.C. 1034 at [18], per Moore-Bick L.J.

${ }^{91}$ K. Rodgers and Joe-han Ho, "TAEL One Partners: contractual interpretation as an iterative process" (2015) 5

J.B.L. 393 at n. 64.
} 
interprets a phrase contained in an industry-wide standard form, ${ }^{92}$ or the judgment defines a commercially significant type of obligation, ${ }^{93}$ or implies a term on the basis of law. ${ }^{94}$

\section{Commercial common sense applied to overcome a "fairly small mistake" in drafting \\ Lord Neuberger M.R. said in Pink Floyd Music Ltd v EMI Records Ltd (2010):95}

"[here] commercial sense means that one...should conclude that the parties made a mistake in referring to 'Records' in [the relevant clause] when [more accurately] they [in fact] intended to refer to the music, lyrics and performance which were recorded on...the Master Tapes. This is a fairly small mistake... and the contention that it was made is not only supported by business common sense, but also by [consulting the rest of the agreement]."

If this is an independent manifestation of "commercial common sense", it overlaps with both "corrective construction", see nn. 41-47, and Rectification, nn. 38-40.

\section{Commercial common sense as a check against absurdity}

In Antaios Cia Naviera SA v Salen Rederierna AB ("The Antaios") (1985) Lord Diplock said:96 "If detailed and syntactical analysis of words in a commercial contract is going to lead to a conclusion that flouts business common sense it must yield to business common sense." See Section IV for expansion of this sub-topic.

\section{Commercial common sense can be used as a compass to point the way when considering rival meanings}

Lord Clarke in the "Rainy Sky" case (2011) made clear that a court need not wait until confronted by an extremely unreasonable or absurd construction before adopting a commercial perspective:"97 "It is not in my judgment necessary to conclude that, unless the most natural meaning of the words produces a result so extreme as to suggest that it was unintended, the court must give effect to that meaning." He added:98 "If there are two possible constructions, the court is entitled to prefer the construction which is consistent with business common sense and to reject the other." Lord Clarke continued: 99 "where a term of a contract is open to

\footnotetext{
92 E.g., the financial instrument considered in: Re Sigma [2009] UKSC 2; [2010] 1 All E.R. 571.

93 E.g., "safe port" warranties in time charterparties: Kodros Shipping Corp of Monrovia v Empresa Cubana de Fletes ("The Evia") [1983] 1 A.C. 736, 757, H.L.

${ }^{94}$ Liverpool City Council v Irwin [1977] A.C. 239, H.L.

95 [2010] EWCA Civ 1429 at [58] (not reproduced at [2011] 1 W.L.R. 770).

${ }^{96}$ [1985] A.C. 191, 201, H.L.

${ }_{97}$ Rainy Sky SA v Kookmin Bank [2011] UKSC 50; [2011] 1 W.L.R. 2900 at [20], [22] to [29] (noted Paul S. Davies [2012] L.M.C.L.Q. 26-29).

${ }^{98}$ Rainy Sky SA v Kookmin Bank [2011] UKSC 50; [2011] 1 W.L.R. 2900 at [21]

99 [2011] UKSC 50; [2011] 1 W.L.R. 2900 at [30].
} 
more than one interpretation, it is generally appropriate to adopt the interpretation which is most consistent with business common sense."

\section{Absurdity}

A long-standing ${ }^{100}$ application of commercial common sense is to avoid a construction which would "flout business common sense"; 101 or would be "commercially irrational"; 102 or something "no businessman in his senses" would accept; ${ }^{103}$ or a "plainly ridiculous" result. 104 An influential statement is by Lord Diplock in "The Antaios" (1984):105 "...if detailed semantic and syntactical analysis of words in a commercial contract is going to lead to a conclusion that flouts business commonsense, it must be made to yield to business commonsense." And he cited himself in Miramar Maritime Corporation v Holborn Oil Trading Ltd (1984) where he had adopted the following formulation: ${ }^{106 " . . . n o ~ b u s i n e s s ~ m a n ~ w h o ~ h a d ~ n o t ~ t a k e n ~ l e a v e ~ o f ~}$ his senses would intentionally enter into a contract which exposed him to a potential liability of this kind..." Similarly, Lord Mustill said in Torvald Klaveness A/S v Arni Maritime Corporation (1994): "no judge will favour an interpretation which produces an obviously absurd result unless the words used drive him to it, since it is unlikely that this is what the parties intended." ${ }^{107}$

However, suggestions concerning "absurdity" soon shade into contentions based on extreme unreasonableness. As Christopher Clarke L.J. noted in Wood v Sureterm Direct Ltd \& Capita Insurance Services Ltd (2015), there can be a range of meanings: ${ }^{108}$

"The more unbusinesslike or unreasonable the result of any given interpretation the more the court may favour a possible interpretation which does not produce such a result and the clearer the words must be to lead to that result. Thus if what is prima facie the natural reading produces a wholly unbusinesslike result, the court may favour another, even if less obvious, reading..."

Lord Reid championed the criterion of "a very unreasonable result" in Schuler (L) AG v Wickman Machine Tool Sales Ltd (1974) ${ }^{109}$ (although not explicitly tied to the world of business

\footnotetext{
100 The idea has a long lineage, e.g., Lord Blackburn in Caledonian Railway Company v North British Railway Company (1880-81) L.R. 6 App. Cas. 114 at 131, H.L.; Grey v Pearson (1857) 6 H.L.C. 61, 106, per Lord Wensleydale. 101 E.g., Antaios Cia Naviera SA v Salen Rederierna AB [1985] A.C. 191, 201, H.L., per Lord Diplock.

${ }_{102}$ MFI Properties Ltd v BICC Group Pension Trust Ltd [1986] 1 All E.R. 974, 976D, per Hoffmann J. ("commercially irrational").

${ }_{103}$ Miramar Maritime Corp v Holborn Oil Trading Ltd [1984] A.C. 676, 682, H.L., per Lord Diplock.

104 Skanska Rashleigh Weatherfoil Ltd v Somerfield Stores Ltd [2006] EWCA Civ 1732; [2007] C.I.L.L. 2449 at [22], per Neuberger L.J.; R. Calnan, Principles of Contractual Interpretation (Oxford: Oxford University Press, 2013) 7.29. 105 Antaios Cia Naviera SA v Salen Rederierna AB [1985] A.C. 191, 200-1, H.L., per Lord Diplock.

106 [1984] A.C. 676, 684-5, H.L.

107 [1994] 1 W.L.R. 1465, 1473, H.L.

108 [2015] EWCA Civ 839 at [31] (affmd. [2017] UKSC 24; [2017] 2 W.L.R. 1095).
} 
or commerce): "The fact that a particular construction leads to a very unreasonable result must be a relevant consideration. The more unreasonable the result the more unlikely it is that the parties can have intended it, and if they do intend it the more necessary it is that they shall make that intention abundantly clear." However, Lord Mustill in Charter Reinsurance Co. Ltd v Fagan (1997) ${ }^{110}$ was underwhelmed by this "criterion", relegating it to a mere "rule of thumb".

As one passes along the spectrum from absurdity, and beyond "very unreasonable" results, one eventually arrives at much less demanding criteria: an "unusual" or "commercially surprising" construction. That degree of disquiet will not move the court. As Andrew Smith J. noted in the BP Oil case (2012), both parties' contentions had fallen short of establishing interpretations which would flout commercial common sense, and they amounted merely to arguments that the opponent's interpretation would "produce a result that businessmen would consider unusual and would be commercially surprising". 111

Another problem is that language which might seem absurd to one judge might not cause even a flicker of concern to another. ${ }^{112}$

Although the case law continues to acknowledge the need to avoid an interpretation which would produce "absurdity", Briggs L.J. noted in Sugarman v CJS Investments LLP (2014) ${ }^{113}$ that this type of argument can overlap with the technique of "corrective construction" (see text at nn. 41-47 above):

"Sometimes, as in the ICS case (1998), ${ }^{114}$ this...is described as a case where the parties must have used the wrong words or syntax, or where something must have gone wrong with the language: see Chartbrook Ltd v Persimmon Homes Ltd [2009] A.C. 1101. Sometimes, as in Antaios Cia Naviera SA $v$ Salen Rederierna AB (1985), the [court approaches the matter by] recognising a requirement for the analysis of words to yield to business common sense, where it would otherwise flout it."

\section{A Guide at Every Contractual Fork-in-the-Road}

\section{Choosing between rival meanings}

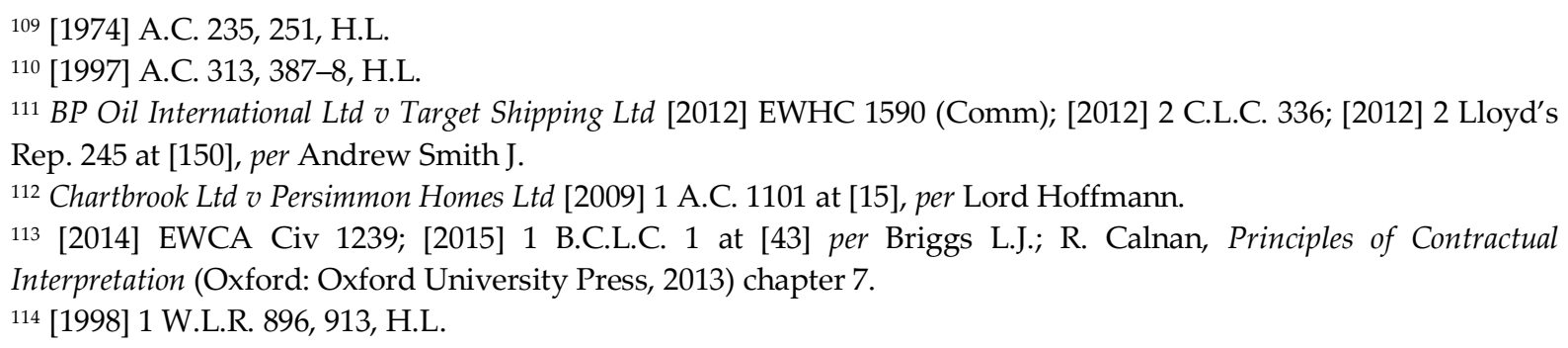


As we have seen in Section IV, commercial common sense is sometimes invoked as a criterion to avoid absurdity. But (as noted in Section III at (5)), CCS has a wider operation. ${ }^{115} \mathrm{~A}$ fundamental statement is by Lord Clarke in the "Rainy Sky" case (2011): 116 "where a term of a contract is open to more than one interpretation, it is generally appropriate to adopt the interpretation which is most consistent with business common sense." This means that where it is clear that one (tenable) meaning is powerfully, or at least clearly, supported by commercial considerations, and a rival (also tenable) argument is not, the court should adopt the first meaning ${ }^{117}$ (unless ${ }^{118}$ perhaps there is another countervailing factor, such as the internal structure of the relevant contract, which fortifies the latter construction).

The intellectual stimulus for this broader function of CCS is Lord Wilberforce's discussion of commercial background and purpose in both Prenn $v$ Simmonds (1971) ${ }^{119}$ and the Reardon case (1976). ${ }^{120}$ Those speeches triggered a judicial chain-reaction. ${ }^{121}$ Thus, ten years after the Reardon case, but a quarter of a century before the "Rainy Sky" (2011), Hoffmann J. in 1986 had captured the spirit of the new approach:122 "if the language is capable of more than one meaning, I think the court is entitled to select the meaning which accords with the apparent commercial purpose of the clause rather than one which appears commercially irrational."

\section{Commercial common sense forms part of the overall objective inquiry}

However, as Lord Neuberger's "restatement" in Arnold v Britton (2015)123 (quoted in Section II above) makes clear, commercial common sense is not an independent criterion operating in tandem with the foremost criterion of objectivity (the two lens theory). Instead commercial common sense is merely part of the objective inquiry to discover the legally operative meaning of the document (the one lens theory). CCS sits alongside other sources of information used by the reasonable reader (in whose imaginary shoes the adjudicator must stand) when construing the document. Similarly, in Pink Floyd Music Ltd v EMI Records Ltd (2010) Lord Neuberger M.R. said that the adjudicator, as a reasonable reader of the contested

115 Napier Park European Credit Opportunities Fund Ltd v Harbourmaster Pro-Rata CLO 2 BV [2014] EWCA Civ 984 at [33], per Lewison L.J.; G. Leggatt, “Making Sense of Contracts: the Rational Choice Theory” (2015) 131 L.Q.R. 454, 470-471.

116 [2011] UKSC 50; [2011] 1 W.L.R. 2900 at [30].

117 E.g., Cohen $v$ Tesco Properties Ltd [2014] EWHC 2442 (Ch) at [31], per Sales J.

118 Fitzhugh v Fitzhugh [2012] EWCA Civ 694; [2012] 2 P. \& C.R. 14 at [17] to [22]; D. McLaughlan, “The Lingering Confusion and Uncertainty in the Law of Contract Interpretation" [2015] L.M.C.L.Q. 406, 432-434.

119 [1971] 1 W.L.R. 1381, 1389, H.L.

120 Reardon Smith Line Ltd v Yngvar Hansen-Tangen [1976] 1 W.L.R. 989: see the long passage at 995-7, per Lord Wilberforce.

${ }^{121}$ E.g., Lord Wilberforce's discussion in the Reardon case (preceding note) was cited by Steyn L.J. in Arbuthnott $v$ Fagan [1995] C.L.C. 1396, 1402, C.A. for the proposition that commercial purpose is relevant at all stages of construction.

${ }^{122}$ MFI Properties Ltd v BICC Group Pension Trust Ltd [1986] 1 All E.R. 974, 976D, per Hoffmann J. (the case contains no reference to the Reardon case [1976] 1 W.L.R. 989, but does refer to Antaios Cia Naviera SA v Salen Rederierna AB [1985] A.C. 191, 200-1, H.L.).

123 [2015] UKSC 36; [2015] A.C. 1619 at [15] (on the decision itself, Zhong Xing Tan, "Beyond the real and the paper deal: the quest for contextual coherence in contractual interpretation" (2016) 79 M.L.R. 623, 6544-652). 
document, must be commercially informed: ${ }^{124}$ "... The words must be interpreted by reference to what a reasonable person (who is informed with business common sense, the knowledge of the parties, including of course the other provisions of the contract, and the experience and expertise enjoyed by the parties, at the time of the contract) would have understood by the provision." In practice, this will be the product of both the court's pool of commercial experience (as it were, "commercial judicial notice") $)^{125}$ and specific information acquired during the course of the case, notably when dealing with a "niche" transaction.

And so there is only one endeavour or exercise, which is the "unitary"126 task of constructing the objective meaning, using the following four main tools or instruments: (1) the words immediately in issue must be read against the whole text (or set of documents), ${ }^{127}$ it being "very dangerous to construe an expression in isolation"128 and the focus on the immediately disputed portion can cause the reader to fail to see the wood for the trees ${ }^{129}$ (earlier concluded documents, but not the parties' negotiations, can become accessible under the factual matrix principle);130 (2) the document's purpose(s); (3) surrounding facts and assumptions, to which the parties are deemed to have been privy at the time of formation; and (4) commercial common sense can be used to avoid absurdity (Section IV above) and it can operate, still more frequently, as a compass to point the way when considering rival meanings (see Section III (6)). However, for all these purposes and at all stages, the adjudicator is denied access to, and must exclude consideration of, declarations of subjective intent and evidence of negotiations or post-formation conduct (for those evidential exclusions, see the text at nn. 34-37 above).

\section{Commercial common sense not to be overplayed}

Lord Neuberger in Arnold $v$ Britton (2015) ${ }^{131}$ urged caution against being influenced by contentions founded on commercial common sense if the text itself seems clear and unproblematic. Those comments were scrutinised in Carillion Construction Limited $v$ Woods Bagot Europe Limited (2016). ${ }^{132}$ That case concerned interpretation of a clause which regulated the extension of time for completion of work under a sub-contract (the building project in question is now the Rolls Building, London, which accommodates parts of the High Court).

\footnotetext{
124 [2010] EWCA Civ 1429 at [18] (not included at [2011] 1 W.L.R. 770).

125 On the (narrow) doctrine of "judicial notice", Phipson on Evidence, 18th ed. (London: Sweet \& Maxwell, 2013), 3-02 ff.

126 Rainy Sky SA v Kookmin Bank [2011] UKSC 50; [2011] 1 W.L.R. 2900 at [21], per Lord Clarke; and Arnold v Britton [2015] UKSC 36; [2015] A.C. 1619 at [76] and [77], per Lord Hodge.

127 RWE Npower Renewables Ltd v JN Bentley Ltd [2013] EWHC 978 (TCC) at [23], per Akenhead J (affmd. [2014] EWCA Civ 150 at [21] ff., per Moore-Bick L.J).

128 Skanska Rashleigh Weatherfoil Ltd v Somerfield Stores Ltd [2006] EWCA Civ 1732; [2007] C.I.L.L. 2449 at [18], per Neuberger L.J.

${ }^{129}$ Re Sigma [2009] UKSC 2; [2010] 1 All E.R. 571 at [12], per Lord Mance.

${ }^{130}$ Enterprise Inns plc $v$ Palmerston Associates Ltd [2011] EWHC 3165 (Ch) at [60], per Morgan J.

131 [2015] UKSC 36; [2015] A.C. 1619 at [16] to [23], per Lord Neuberger.

132 [2016] EWHC 905 (TCC); [2016] B.L.R. 382; affmd. [2017] EWCA Civ 65 at [46], Jackson LJ said: `Recent case law establishes that only in exceptional circumstances can considerations of commercial common sense drive the court to depart from the natural meaning of contractual provisions. See Arnold at [19] to [20].'
} 
The judge (Nerys Jefford Q.C.) adopted, as a matter of ordinary construction, the subcontractor's suggested interpretation. Having listed the salient points made by Lord Neuberger in Arnold $v$ Britton ${ }^{133}$ the judge in the Carillion case formulated this summary: ${ }^{134}$

"the court should first look for the natural meaning of the words used in the contract and not be too ready to depart from the natural meaning on the basis of the meaning the court thinks accords with commercial common sense. However, the more unclear the words or the worse the drafting, the more ready the court should be to do so. When considering the parties' intended commercial meaning of the words used, the court should be careful to have regard only to what the parties knew or could reasonably have known at the time of entering into the contract."

The judge, Nerys Jefford Q.C., then explained that, in her view (which has been upheld by the Court of Appeal), the present clause was unproblematic ${ }^{135}$ and "clear" (noting that a court should then be slow to deviate from that view reached by textual examination and regard to the factual matrix). ${ }^{136}$ But in any event, the judge added, the interpretation adopted was not commercially objectionable: 137 "I do not, however, consider that this meaning does not accord with commercial common sense. [The sub-contractor's] interpretation...is practicable and workable and is what a reasonable person with all the background knowledge of the parties would have thought the clause meant at the time the contract was entered into."

The text is the primary source of guidance. It might emerge from the forensic debate that there is more than one possible construction. But the document cannot be tortured, in the name of commercial common sense, into yielding a "rival" meaning which has no support at all in the text. A choice can be made, but only if there are genuine rivals. Commercial common sense is not a magician capable of pulling rabbits out of thin air. To quote again from the "Rainy Sky" case (2011), Lord Clarke made clear that CCS enables the judge to umpire as between "two [or more] possible constructions", 138 that is, "where a term of a contract is open to more than one interpretation". ${ }^{139}$ Even then, CCS does not command the whole field. Instead it remains important to keep in view the entire document. As Lord Clarke explained, the court is engaged in "an iterative process, involving checking each of the rival meanings against other provisions of the document and investigating its commercial consequences" (emphasis added). ${ }^{140}$

${ }^{133}$ [2016] EWHC 905 (TCC); [2016] B.L.R. 382, at [34]; affmd. [2017] EWCA Civ 65.

134 [2016] EWHC 905 (TCC); [2016] B.L.R. 382, at [35]; affmd. [2017] EWCA Civ 65.

135 [2016] EWHC 905 (TCC); [2016] B.L.R. 382, at [60]; affmd. [2017] EWCA Civ 65.

136 [2016] EWHC 905 (TCC); [2016] B.L.R. 382, at [61]; affmd. [2017] EWCA Civ 65.

137 [2016] EWHC 905 (TCC); [2016] B.L.R. 382, at [61], see also [60]; affmd. [2017] EWCA Civ 65.

138 Rainy Sky SA v Kookmin Bank [2011] UKSC 50; [2011] 1 W.L.R. 2900 at [21].

139 [2011] UKSC 50; [2011] 1 W.L.R. 2900 at [30].

140 [2011] UKSC 50; [2011] 1 W.L.R. 2900 at [28] (drawing on remarks by Lord Neuberger in Re Sigma [2008] EWCA Civ 1303; [2009] B.C.C. 393 at [98], [115] and [131]). For an illustration of this "iterative" process, TAEL One Partners Ltd $v$ Morgan Stanley \& Co International plc [2015] UKSC 12; [2015] 4 All E.R. 545 at [37] and [41] to [45], per Lord Reed (noted K. Rodgers and Joe-han Ho (2015) 5 J.B.L. 393-409). 
Even before Arnold $v$ Britton (see discussion in the previous paragraphs), the post-Rainy Sky case law had made clear that a putative "rival" meaning must be tenable, having regard to the text and its factual matrix. In Procter \& Gamble Company v Svenska Cellulosa Aktiebolaget SCA (2012), Moore-Bick L.J. said that if the language is "reasonably capable of being given two possible meanings" then, but only then, "the court should prefer that [meaning] which better accords with the overall objective of the contract or with good commercial sense". ${ }^{141}$ Similarly, other cases have referred to "genuinely alternative meanings of an ambiguous provision", ${ }^{142}$ or "language capable of bearing" different meanings, ${ }^{143}$ or a "material ambiguity"144 (Akenhead J. noting in the RWE Npower case (2013): "Often, on analysis, apparent ambiguities are not ambiguities at all"). ${ }^{145}$ The court is required to conduct a "holistic" or "global" examination of the whole contract in order to determine whether real ambiguity exists or whether the suggested doubt is in fact a mirage ${ }^{146}$ (although, it is suggested, the better ${ }^{147}$ usage is not "ambiguity" but "alternative reading"148 or lack of clarity). Lewison L.J. expressed the issue clearly in the Napier Park case (2014): "Once an alternative reading emerges as a possible meaning, the interpreter must go on to consider which of two or more possible meanings is the more commercially sensible." 149 As Lord Hodge put it crisply in Arnold v Britton (2015): 150 "there must be a basis in the words used and the factual matrix for identifying a rival meaning".

\section{Clear language causing countervailing commercial common sense points to melt away}

No lack of clarity was discerned in Edgeworth Capital (Luxembourg) SARL $v$ Ramblas Investments BV (2015). And so Hamblen J. concluded that arguments based on "commerciality" had failed to reach the target. ${ }^{151}$ Similarly, Henderson J. in the Flanagan case (2015) held that a notice period specified in a limited liability partnership agreement contained no ambiguity and so it was unnecessary for him on that occasion to consider arguments founded on commercial common sense. ${ }^{152}$

\footnotetext{
${ }^{141}$ [2012] EWCA Civ 1413 at [22], per Moore-Bick L.J.

${ }^{142}$ LB Re Financing No. 3 Ltd v Excalibur Funding No. 1 plc [2011] EWHC 2111 (Ch) at [46], per Briggs J.

${ }^{143}$ Sugarman v CJS Investments LLP [2014] EWCA Civ 1239; [2015] 1 B.C.L.C. 1 at [28], per Floyd L.J.

${ }_{144}$ RWE Npower Renewables Ltd v JN Bentley Ltd [2013] EWHC 978 (TCC) at [30], per Akenhead J. (upheld [2014] EWCA Civ 150).

${ }^{145}$ RWE Npower case [2013] EWHC 978 (TCC) at [23].

${ }^{146}$ RWE Npower case [2013] EWHC 978 (TCC) at [24], per Akenhead J. (upheld [2014] EWCA Civ 150).

147 Sans Souci Ltd v VRL Services Ltd [2012] UKPC 6 at [14], per Lord Sumption.

148 Napier Park European Credit Opportunities Fund Ltd v Harbourmaster Pro-Rata CLO 2 BV [2014] EWCA Civ 984 at [26], per Lewison L.J.

${ }^{149}$ Napier Park case [2014] EWCA Civ 984 at [26], per Lewison L.J.

150 Arnold v Britton [2015] UKSC 36; [2015] A.C. 1619 at [77].

151 [2016] 1 All E.R. (Comm.) 368 at [45] to [48].

152 Flanagan v Liontrust Investment Partners LLP [2015] EWHC 2171 (Ch); [2015] Bus. L.R. 1172; [2016] 1 B.C.L.C. 177, per Henderson J. at [132] to [136].
} 
In Cottonex Anstalt $v$ Patriot Spinning Mills Ltd (2014) Hamblen J. suggested that there is no mechanical rule of construction that the court will accede to an interpretation just because one party has sought to bolster it by an appeal to business sense. ${ }^{153}$ Everything must depend on the lack of clarity of the text:154 "The more ambiguous the meaning and the stronger the business common sense arguments the more likely it is to be appropriate to do so." These comments indicate that an argument founded on commercial common sense will not induce the court to adopt a disputed construction in one party's favour if that argument has only "marginal" weight and there is little ambiguity. ${ }^{155}$ A fortiori, Hamblen J. is making clear that commercial common sense should not tip the balance when the court is satisfied that the text, construed in context, provides a clear answer. ${ }^{156}$

Similarly, Leggatt J. said in Tartsinis v Navona Management Co (2015): ${ }^{157}$ “There is... a need for caution in relying on arguments of 'commercial common sense', particularly when they conflict with the intention naturally to be inferred from the language which the parties have chosen to express their bargain."

\section{VI. “There May be Trouble Ahead"158}

It is clear that commercial common sense must not get too big for its boots. The main problems arising under the post-"Rainy Sky" (2011) regime ${ }^{159}$ will now be presented under these headings: (1) confusion: the battle of party assertion; (2) competence: judges should know the limits of their commercial experience; (3) textual fidelity: parties make contracts and not judges; (4) courts are not to be swayed by "sympathy" for one side.

\section{Confusion: the battle of party assertion}

Judges are wary of parties who present exaggerated or flimsy appeals to CCS. Often each party seeks to "trumpet" 160 commercial common sense with more or less equal plausibility, so that they are in truth engaged in making rival assertions of commercial attractiveness or reasonableness, and presenting arguments which "fly in different directions" or are "not clear-cut" ${ }^{161}$ One party's commercial common sense is an opponent's commercial nonsense.

\footnotetext{
${ }^{153}$ Cottonex Anstalt v Patriot Spinning Mills Ltd [2014] EWHC 236 (Comm); [2014] 1 Lloyd's Rep. 615 at [56], per Hamblen J.

${ }^{154}$ Cottonex case [2014] EWHC 236 (Comm); [2014] 1 Lloyd's Rep. 615 at [56].

155 Cf., Cottonex case [2014] EWHC 236 (Comm); [2014] 1 Lloyd's Rep. 615 at [74]; Globe Motors Inc v TRW Lucas Varity Electric Steering Ltd [2016] EWCA Civ 396; [2017] 1 All E.R. (Comm) 601 at [60], per Beatson L.J.

156 Soufflet Negoce SA v Fedcominvest Europe Sarl [2014] EWHC 2405 (Comm); [2014] 2 Lloyd's Rep. 537; [2014] 2 C.L.C. 39 at [19] to [29], per Eder J.

157 Tartsinis v Navona Management Co [2015] EWHC 57 (Comm) at [54].

158 "There may be trouble ahead

But while there's moonlight

And music and love and romance

Let's face the music and dance.' (Nat King Cole)

159 Rainy Sky SA v Kookmin Bank [2011] UKSC 50; [2011] 1 W.L.R. 2900 (see text at nn. 97-99 and 138-139 above).

160 Aston Hill Financial Inc v African Minerals Finance Ltd [2012] EWHC 2173 (Comm) at [27], per Eder J. (affmd. [2013] EWCA Civ 416).

161 Aston Hill case [2012] EWHC 2173 (Comm) at [31], per Eder J. (affmd. [2013] EWCA Civ 416).
} 
Dead-lock ${ }^{162}$ can be produced by the collision of "reasonable arguments both ways". ${ }^{163}$ Intellectually honest judges must then admit that they cannot "conclude with confidence that there is an interpretation which makes more business common sense" and that, in such a situation, it is "often difficult for a court of law to make nice judgments as to where business common sense lies."164 As Lord Mustill warned: "where there is no obvious difficulty, and simply assertions by either side that its own interpretation yields the more sensible result, there is room for error". 165

A controversial resort to notions of "commercial common sense" is the Court of Appeal's difficult decision in Rice v Great Yarmouth Borough Council (2000). ${ }^{166}$ This was a four-year contract for the maintenance by the claimant of the defendant's sports and parks facilities. The written contract gave the defendant the right to terminate for "breach of any of [Rice's] obligations under the Contract". But it was held that "any" (a short word which means "any") should not be taken to mean "any at all", otherwise the parties would have created a "draconian" contractual regime, ${ }^{167}$ and that would "fly in the face of commercial sense". Instead "any" was construed as code for "any repudiatory" breach. ${ }^{168}$ The Court of Appeal, therefore, concluded that termination would be justified only if there had been "repudiation" by a pattern of breaches. ${ }^{169}$ But the breaches had not been cumulatively serious enough on these facts. The case has excited much critical comment. ${ }^{170}$

\section{Competence: judges should know the limits of their commercial experience}

Civil judges must not assume that they are masters of all trades, including "fishmongers and carriers of fish", 171 or experienced mariners, etc. Unlike specialist arbitrators chosen for specific market experience (for example, as engineers or commodity traders), civil judges are not selected as possessing hands-on mercantile experience. ${ }^{172}$ Instead judges are mostly generalist civil practitioners. In the Skanska case (2006) Neuberger L.J. warned:173 "Judges are

162 E.g., ENER-G Holdings plc v Hormell [2012] EWCA Civ 1059; [2013] 1 All E.R. (Comm.) 1162 at [57], per Gross L.J. (although Lord Neuberger M.R. at [31] to [33] identified strong commercial reasons).

${ }^{163}$ Kahn v Dunlop Haywards (DHL) Ltd [2007] EWHC 2659 (QB) at [65], per Foskett J.

164 Cottonex Anstalt v Patriot Spinning Mills Ltd [2014] EWHC 236 (Comm); [2014] 1 Lloyd's Rep. 615 at [57], per Hamblen J.

165 Torvald Klaveness A/S v Arni Maritime Corporation [1994] 1 W.L.R. 1465, 1473, H.L.

166 The Times, 26 July 2000; (2001) 3 L.G.L.R. 4, C.A.

167 The Times, 26 July 2000; (2001) 3 L.G.L.R. 4 at [22], per Hale L.J.

168 The Times, 26 July 2000; (2001) 3 L.G.L.R. 4, adopting Antaios Compania Naviera SA v Salen Rederierna AB [1985] A.C. 191, 200-1, H.L.

169 Rice v Great Yarmouth Borough Council, The Times, 26 July 2000; (2001) 3 L.G.L.R. 4, C.A. at [17], per Hale L.J.

170 E.g., M. Chen-Wishart, Contract Law, 5th ed. (Oxford: Oxford University Press, 2015), 493; E. McKendrick, Text, Cases, and Materials, 7th ed. (Oxford: Oxford University Press, 2016), 787.

${ }_{171}$ Manchester Sheffield \& Lincolnshire Railway Co v Brown (1883) 8 App. Cas. 703, 716, H.L., per Lord Bramwell: "here is a contract made by a fishmonger and a carrier of fish who know their business, and whether it is just and reasonable is to be settled by me who am neither fishmonger nor carrier, nor with any knowledge of their business".

172 Cf. in the USA, on rejection of "merchant tribunals", Robert E. Scott, "The Rise and Fall of Article 2" (2002) 62 Louisiana L. Rev. 1009, 1034-1035.

173 Skanska Rasleigh Weatherfoil Ltd v Somerfield Stores Ltd [2006] EWCA Civ 1732; [2007] C.I.L.L. 2449 at [22]. 
not always the most commercially-minded, let alone the most commercially experienced, of people, and should, I think, avoid arrogating to themselves overconfidently the role of arbiter of commercial reasonableness or likelihood." And in an extra-judicial speech, Lord Neuberger said in 2014:174 “... judges should be diffident before pontificating about the commercial realities of any particular interpretation...[It] does not seem obvious that a judge, who is normally fairly remote from business matters, would be particularly good at identifying the commercial common sense of any conclusion, let alone what a reasonable person might regard as commercially sensible." As Lewison (2015) ${ }^{175}$ comments, "neither the advocates who argue points of construction nor the judges who determine them are commercial men" and so they should refrain from latching on to "a preconceived idea of what contracts of that description generally seek to achieve" and then trying to "force the words of the particular contract to fit that preconception".

However, in some contexts it is clear that judges have acquired profound and secure understanding of a particular type of transaction. A good example is Hoffmann J.'s treatment of a rent review clause in MFI Properties Ltd $v$ BICC Group Pension Trust Ltd (1986). ${ }^{176}$ His judgment is a magisterial analysis of the commercial background to such a clause. His commercial understanding of this type of clause legitimately influenced his appreciation of its legal effect. And it is salutary to recall that in the "Rainy Sky" litigation, the Supreme Court's decision ${ }^{177}$ vindicated Simon J.'s first instance conclusion, ${ }^{178}$ and that, in the Court of Appeal, Sir Simon Tuckey, the dissenting judge, had favoured this same analysis, commenting that: ${ }^{179}$ "As an experienced commercial judge [Simon J.'s] conclusion... should be given considerable weight by this Court."

\section{Textual fidelity: parties make contracts and not judges}

Richard Calnan, a London practitioner and leading commentator, has said:180 "Business people from all over the world choose English law because English law holds the parties to their bargains...The courts enforce what has been agreed, not what they think might better have been agreed. It is the great strength of English commercial law."

Commercial common sense is not an "overriding criterion"181 and should not become an incantation deployed simply to "to undervalue the importance of the [contractual]

\footnotetext{
${ }^{174}$ Lord Neuberger, "The impact of pre-and post-contractual conduct on contractual interpretation" (Banking Services and Finance Law Association Conference, Queenstown, 2014) at [18] (<https://www.supremecourt.uk/docs/speech-140811.pdf $>$ last accessed 2 September, 2016).

175 Lewison on the Interpretation of Contracts, 6th ed. (London: Sweet \& Maxwell, 2015), 2.08, concluding paragraph, page 69.

${ }_{176}$ MFI Properties Ltd v BICC Group Pension Trust Ltd [1986] 1 All E.R. 974.

177 Rainy Sky SA v Kookmin Bank [2011] UKSC 50; [2011] 1 W.L.R. 2900.

178 [2009] EWHC 2624 (Comm); [2010] 1 All E.R. (Comm.) 823.

179 Kookmin Bank v Rainy Sky SA [2010] EWCA Civ 582; [2011] 1 All E.R. (Comm.) 18; [2011] 1 Lloyd's Rep. 233 at [30].

180 R. Calnan, Principles of Contractual Interpretation (Oxford: Oxford University Press, 2013), 7.14.

181 Jackson v Dear [2012] EWHC 2060 (Ch) at [40] (vii), per Briggs J. (reversed, but not on this point, [2013] EWCA Civ 89; [2014] 1 B.C.L.C. 186).
} 
language." 182 The court lacks the power to "rewrite"183 the language "merely because its terms seem somewhat unexpected, a little unreasonable, or not commercially very wise" 184 or, as Lord Mustill famously stated, in Charter Reinsurance Co Ltd v Fagan (1997), "to substitute for the bargain actually made one which the court believes could better have been made". ${ }^{185}$ The courts must not fall into the "trap" of rewriting the contract to achieve a more "reasonable meaning". ${ }^{186}$ As Rix L.J. said in the ING case (2011) "construction cannot be pushed beyond its proper limits in pursuit of remedying what is perceived to be a flaw in the working of a contract", unless the solution (on the basis of "corrective construction", see text at nn. 41-47 above) to the flaw can be found "within the four walls of the contract itself", 187 or unless, based on evidence extrinsic to the document, the doctrine of Rectification can be invoked (on which see text at nn. 38-40 above). Commercial common sense must not be used to "subject the parties to the individual judge's own notions of what might have been the most sensible solution to the parties' conundrum". ${ }^{188}$ As Lord Neuberger commented in Arnold $v$ Britton (2015): "The clearer the natural meaning the more difficult it is to justify departing from it."189

There are many examples of strong appellate courts refusing to be blown off-course by appeals to the allegedly "uncommercial" nature of the contractual language, notably Deutsche Genossenschaftsbank v Burnhope (1995), ${ }^{190}$ concerning the scope of an insurance contract, and City Alliance Ltd v Oxford Forecasting Services Ltd (2001), concerning a corporate share option. ${ }^{191}$ Nor can commercial common sense justify inserting an implied term into a commercial document when the suggested revision is contestable and not supported by the traditional yardsticks of obviousness and commercial necessity. ${ }^{192}$

Furthermore, courts should keep open the possibility that a difficult, odd, obscure, or tough point of drafting is the result of give-and-take, and thus a compromise ${ }^{193}$ (a transactional "trade-off 194 or "quid pro quo"), ${ }^{195}$ or simply a case of deliberate obfuscation. ${ }^{196}$ On this last

\footnotetext{
${ }^{182}$ Arnold v Britton [2015] UKSC 36; [2015] A.C. 1619 at [17], per Lord Neuberger.

183 [2015] UKSC 36; [2015] A.C. 1619 at [18] to [20], [77], [110].

184 Skanska Rashleigh Weatherfoil Ltd v Somerfield Stores Ltd [2006] EWCA Civ 1732; [2007] C.I.L.L. 2449 at [21], per Neuberger L.J.

185 [1997] A.C. 313, 388, H.L.

186 Procter and Gamble Co v Svenska Cellulosa Aktiebolaget SCA [2012] EWCA Civ 1413 at [22], per Moore-Bick L.J.

187 ING Bank NV v Ros Roca SA [2011] EWCA Civ 353; [2012] 1 W.L.R. 472 at [110].

188 Jackson v Dear [2012] EWHC 2060 (Ch) at [40] (vii) per Briggs J.

189 Arnold v Britton [2015] UKSC 36; [2015] A.C. 1619 at [18], per Lord Neuberger.

190 [1995] 1 W.L.R. 1580, H.L. (Lord Steyn dissented).

191 [2001] 1 All E.R. Comm. 156 at [13].

192 Jackson v Dear [2013] EWCA Civ 89; [2014] 1 B.C.L.C. 186 at [22] and [41], per McCombe L.J.; Marks \& Spencer $v$ BNP Paribas [2015] UKSC 72; [2016] A.C. 742, at [16] and [17], affirming "The Moorcock" (1889) 14 P.D. 64, 68, C.A., per Bowen L.J. and Shirlaw v Southern Foundries (1926) Ltd [1939] 2 K.B. 206, 227-228, C.A., per MacKinnon L.J. (affmd. [1940] A.C. 701, H.L.).

${ }_{193}$ Chartbrook Ltd $v$ Persimmon Homes Ltd [2009] UKHL 38; [2009] 1 A.C. 1101 at [20], per Lord Hoffmann; Wood v Sureterm Direct Ltd \& Capita Insurance Services Ltd [2015] EWCA Civ 839 at [29] (affmd. [2017] UKSC 24; [2017] 2 W.L.R. 1095).

194 Grove Investments Ltd v Cape Building Products Ltd [2014] CSIH 43; (2014) Hous. L. Rep. 35 at [10], per Lord Drummond Young.
} 
point, Lord Wilberforce noted in Prenn $v$ Simmonds (1971): 197 "The words used may, and often do, represent a formula which means different things to each side, yet may be accepted because that is the only way to get 'agreement' and in the hope that disputes will not arise. The only course then can be to try to ascertain the 'natural' meaning." In Re Sigma (2009) Lord Neuberger captured well the reality of many professionally drafted documents: ${ }^{198}$

"they often have different provisions drafted inserted or added to by different lawyers at different times; they often include last-minute amendments agreed in a hurry, frequently in the small hours of the morning after intensive negotiations, with a view to achieving finality rather than clarity; indeed, often the skill of the drafting lawyer is in producing obscurity, rather than clarity, so that two inconsistent interests can feel satisfied with the result."

In the absence of a concurrent Rectification claim (see text at nn. 38-40 above), these matters are concealed behind the curtain of the pre-contractual negotiation evidence bar (see text at nn. 35-36 above): "the reasonable addressee of the instrument has not been privy to the negotiations and cannot tell whether a provision favourable to one side was not in exchange for some concession elsewhere or simply a bad bargain."199 The court will not engage in "guessing"200 what the negotiations might have been: that would be "pure speculation"201 because it is "impossible, and in any event impermissible, to try to recreate the thinking of either party in the negotiations". 202

For this reason, the Court of Appeal (upheld by the Supreme Court) in Wood v Sureterm Direct Ltd \& Capita Insurance Services Ltd (2015) ${ }^{203}$ reversed the first instance judge, who had given a wide scope to an indemnity clause in a share purchase agreement. The Court of Appeal said that the judge's decision to fill a so-called "gap" in the scope of an indemnity was unsafe. The very question whether there was a gap was contestable. Even if truly there had been a gap, this might not have been the result of an over-sight in the drafting, but instead the conscious outcome of hard-fought negotiation. However, the court cannot probe these uncertainties. As Christopher Clarke L.J. said:204 "the court will not be aware of the negotiations between the parties. What may appear, at least from one side's point of view, as lacking in business

\footnotetext{
195 MFI Properties Ltd v BICC Group Pension Trust Ltd [1986] 1 All E.R. 974, 976, per Hoffmann J.; Aston Hill Financial Inc v African Minerals Finance Ltd [2013] EWCA Civ 416 at [23].

196 Royal Society for the Prevention of Cruelty to Animals v Sharp [2010] EWCA Civ 1471; [2011] 1 W.L.R. 980 at [32], per Lord Neuberger M.R.

197 [1971] 1 W.L.R. 1381, 1385, H.L.

198 Re Sigma [2008] EWCA Civ 1303; [2009] B.C.C. 393 at [100], per Lord Neuberger (his dissenting judgment was preferred on appeal: [2009] UKSC 2; [2010] 1 All E.R. 571).

199 Chartbrook Ltd v Persimmon Homes Ltd [2009] UKHL 38; [2009] 1 A.C. 1101 at [20], per Lord Hoffmann; Firm PI 1 Ltd $v$ Zurich Australian Insurance Ltd [2014] NZSC 147; [2015] 1 N.Z.L.R. 432 at [91], per Arnold J.

200 Safeway Food Stores Ltd v Banderway Ltd (1983) 2 E.G.L.R. 116, per Goulding J.

${ }^{201}$ MFI Properties Ltd v BICC Group Pension Trust Ltd [1986] 1 All E.R. 974, 976F, per Hoffmann J.

202 Pink Floyd Music Ltd v EMI Records Ltd [2010] EWCA Civ 1429 at [81], per Carnwath L.J. (a problem which led him to dissent) (passage not included at [2011] 1 W.L.R. 770).

${ }^{203}$ [2015] EWCA Civ 839 (affmd. [2017] UKSC 24; [2017] 2 W.L.R. 1095).

204 [2015] EWCA Civ 839 at [29]; affmd. [2017] UKSC 24; [2017] 2 W.L.R. 1095.
} 
common sense, may be the product of a compromise which was the only means of reaching agreement."

On the other hand, the court might conclude that the contract is simply "incoherent" 205 or "badly constructed". ${ }^{206}$ As Lord Neuberger admitted in Arnold v Britton (2015): "when it comes to considering the centrally relevant words to be interpreted, I accept that the less clear they are, or, to put it another way, the worse their drafting, the more ready the court can properly be to depart from their natural meaning." 207 If, despite earnest attempts to find linguistic clues, the relevant text does not provide a reliable answer, the court can appropriately abandon "semantic niceties" and instead concentrate on trying to achieve a business-like construction. ${ }^{208}$ This is not uncommon, as Arden L.J. explained in the Golden Key case (2009):209

"The court can spend a great deal of time immersed in the detail of lengthy contractual documents searching for clues. That task has to be carried out but if, despite a thorough search, the position is still unclear, and more than one meaning is properly available, the right approach is surely to give greater weight to the presumption that the parties must have intended some commercial result than to the textual clues if the latter yields an uncommercial result."

However, judges should not despair too quickly. The courts must not be linguistically overfastidious. Judges might trip themselves up by latching onto the fact that the document contains "flaws" 210 or textual "infelicity" or that it is badly structured. Nearly every great work of literature is flawed and business is often conducted in a hurry. Commercial documents will not have been proof-read by Ezra Pound. The court will take into account the fact that the contract has been composed by lay persons without legal assistance, ${ }^{211}$ or at least that it was "not finalised by lawyers".212 Even when considering professionally drafted documents, courts should not become fixated by tautology ${ }^{213}$ or erratic punctuation. ${ }^{214}$

\footnotetext{
205 Sinochem International Oil (London) Co Ltd $v$ Mobil Sales \& Supply Corporation [2000] 1 All E.R. (Comm.) 474; [2000] 1 Lloyd's Rep. 339; [2000] C.L.C. 878, C.A. at [11], per Mance L.J.

${ }^{206}$ Mitsui Construction Co Ltd v Att-Gen of Hong Kong (1986) 33 B.L.R. 1, 14; (1986) 10 Con. L.R. 1; [1987] H.K.L.R. 1076, P.C., per Lord Bridge.

${ }^{207}$ Arnold v Britton [2015] UKSC 36; [2015] A.C. 1619 at [18], per Lord Neuberger.

208 Sinochem International Oil (London) Co Ltd v Mobil Sales \& Supply Corporation [2000] 1 All E.R. (Comm.) 474; [2000] 1 Lloyd's Rep. 339 C.A. at [27], and [29], per Mance L.J.; Kennedy L.J. dissented.

${ }^{209}$ Re Golden Key Ltd [2009] EWCA Civ 636 at [29], per Arden L.J.; Cohen v Tesco Properties Ltd [2014] EWHC 2442 (Ch) at [30], per Sales J.

${ }^{210}$ In Globe Motors Inc v TRW Lucas Varity Electric Steering Ltd [2016] EWCA Civ 396; [2017] 1 All E.R. (Comm) 601 at [75] Beatson L.J. admitted that "the Agreement was poorly drafted", but this did not prevent the court from subjecting it to textual scrutiny (at [78], [79] and [84] to [87]).

211 Thorney Park Golf Ltd v Myers Catering Ltd [2015] EWCA Civ 19 at [24], per McCombe L.J.; Xia Zhengyan v Geng Changqing [2015] SGCA 22; [2015] 3 S.L.R. 732 at [45] to [60] (document translated from Chinese and drafted without legal advice).

${ }^{212}$ Caution is required: see nn. 224-227 below on the reversal in Globe Motors Inc $v$ TRW Lucas Varity Electric Steering Ltd [2016] EWCA Civ 396; [2017] 1 All E.R. (Comm) 601, notably at [36], [37], [83] [84], of [2014] EWHC 3718 (Comm).

${ }^{213}$ Wood v Sureterm Direct Ltd \& Capita Insurance Services Ltd [2015] EWCA Civ 839 at [49] (affmd. [2017] UKSC

24; [2017] 2 W.L.R. 1095); Maintech Services Pty Ltd v Stein Heurtey SA [2014] NSWCA 184; (2014) 89 N.S.W.L.R.
} 
Furthermore, in the case of complex documents, even if they have been composed with the assistance of lawyers, "there are bound to be ambiguities, infelicities and inconsistencies". ${ }^{215} \mathrm{It}$ is also possible that a document's stylistic or textual shortcomings are in fact irrelevant to the disputed portion of text under consideration. ${ }^{216}$

\section{Courts are not to be swayed by "sympathy" for one side}

"Bad bargains cannot be mended" 217 by the court, even if they have turned out to work "disastrously"218 for one party. In Arnold v Britton (2015) Lord Neuberger said:219 "while commercial common sense is a very important factor,...it is not the function of a court when interpreting an agreement to relieve a party from the consequences of his imprudence or poor advice." Similarly, in Wood v Sureterm Direct Ltd \& Capita Insurance Services Ltd (2015) Christopher Clarke L.J. said:220

"Businessmen sometimes make bad or poor bargains for a number of different reasons such as a weak negotiating position, poor negotiating or drafting skills, inadequate advice or inadvertence. If they do so it is not the function of the court to improve their bargain or make it more reasonable by a process of interpretation which amounts to rewriting it."

Interpretation should be conducted in an even-handed manner, from "the perspective of both parties", and issues of commercial purpose must reflect joint aims "and not just one party's". ${ }^{221}$ Lord Hoffmann said in Chartbrook Ltd v Persimmon Homes Ltd (2009):222 "...the fact that a contract may appear to be unduly favourable to one of the parties is not a sufficient reason for supposing that it does not mean what it says." The court must not be "swayed by sympathy for one side". .223

633 at [105] to [107], per Leeming J.A.

214 [2015] EWCA Civ 839 at [50] (affmd. [2017] UKSC 24; [2017] 2 W.L.R. 1095).

${ }^{215}$ Re Sigma [2009] UKSC 2; [2010] 1 All E.R. 571 at [12] and [37] (see also [2008] EWCA Civ 1303; [2009] B.C.C. 393 at [100].

${ }^{216}$ Arnold v Britton [2015] UKSC 36; [2015] A.C. 1619 at [18], per Lord Neuberger.

${ }^{217}$ LB Re Financing No. 3 Ltd v Excalibur Funding No. 1 plc [2011] EWHC 2111 (Ch) at [45], per Briggs J.

218 Arnold v Britton [2015] UKSC 36; [2015] A.C. 1619 at [19], per Lord Neuberger. Contrast, adopting a quite different perspective under Scots law, Grove Investments Ltd v Cape Building Products Ltd [2014] CSIH 43; (2014) Hous L Rep. 35 at [10], per Lord Drummond Young.

219 [2015] UKSC 36; [2015] A.C. 1619 at [20].

220 [2015] EWCA Civ 839 at [30] (affmd. [2017] UKSC 24; [2017] 2 W.L.R. 1095), Clarke LJ (CA) quoting Arnold v Britton [2015] UKSC 36; [2015] A.C. 1619 at [20], per Lord Neuberger.

${ }^{221}$ Norwich Union Life and Pensions v Linpac Mouldings Ltd [2010] 1 P. \& C.R. 218 at [44], per Lewison J. (affmd. [2010] EWCA Civ 395; [2010] L. \& T.R. 10); Aston Hill Financial Inc v African Minerals Finance Ltd [2013] EWCA Civ 416 at [24], per Aikens L.J.

222 [2009] UKHL 38; [2009] 1 A.C. 1101 at [20].

${ }^{223}$ RWE Npower Renewables Ltd v JN Bentley Ltd [2013] EWHC 978 (TCC) at [22], per Akenhead J (affmd. [2014] EWCA Civ 150). 
It is also a fallacy to suppose that the contract must be read as an expression of equal entitlement. As Beatson L.J.'s cogent analysis of a long-term exclusivity supply agreement in the Globe Motors case (2016) ${ }^{224}$ demonstrates, judges must be attuned to the internal structure of the transaction and the balance of forces which that structure reveals. In that case the Court of Appeal overruled 225 the judge who had unacceptably "read in" words and reached a conclusion which was at odds with the true balance of interests reflected in the document. Although the trial judge had said that it is not the province of the court to re-make the contract by devising "a reasonable and appropriate contract term to suit the judge's view of the circumstances"226 and instead the judicial task is to show fidelity to the text, the judge was shown by the Court of Appeal to have fallen into this very trap. His decision was reversed because he had injected, under the guise of interpretation, an obligation which was not supported by the text.227

In Arnold v Britton (2015) the Supreme Court emphasised that commercial common sense is not an ex post facto release mechanism capable of responding "retrospectively" 228 to one party's "regrets" that the contract has worked out badly.229 It would be wrong to rewrite a clear clause in the interest of abstract fairness: ${ }^{230}$ "[construction is not intended] to rewrite the parties' agreement because it was unwise to gamble on future economic circumstances in a long term contract or because subsequent events have shown that the natural meaning of the words has produced a bad bargain for one side." The Supreme Court instead suggested that the cure on those facts, which concerned "wretchedly conceived clauses", 231 might be either mediation $^{232}$ or legislation, ${ }^{233}$ but not verbal manipulation or textual reconstruction by a court.

In MSC Mediterranean Shipping Co SA v Cottonex Anstalt (2016) Moore-Bick L.J. roundly declared that there is no general principle of good faith "in matters of contract". ${ }^{234}$ This is not the occasion to enter into the merits of that traditional position. ${ }^{235}$ At first instance in that case, Leggatt J. had held that it was against good faith for an owner of sea cargo containers

${ }^{224}$ Globe Motors Inc $v$ TRW Lucas Varity Electric Steering Ltd [2016] EWCA Civ 396; [2017] 1 All E.R. (Comm) 601 at [83] to [87].

225 [2016] EWCA Civ 396; [2017] 1 All E.R. (Comm) 601 at [83] and [85].

226 Globe Motors case [2014] EWHC 3718 (Comm) at [181], per Judge Mackie Q.C.

227 The false step in the trial judge's construction is pin-pointed by Beatson L.J., [2016] EWCA Civ 396; [2017] 1

All E.R. (Comm) 601 at [36], [37], [83] [84].

228 Arnold v Britton [2015] UKSC 36; [2015] A.C. 1619 at [19], per Lord Neuberger.

${ }^{229}$ RWE Npower Renewables Ltd v JN Bentley Ltd [2013] EWHC 978 (TCC) at [22], per Akenhead J. (affmd. [2014] EWCA Civ 150).

${ }^{230}$ [2015] UKSC 36; [2015] A.C. 1619 at [70], per Lord Hodge; Procter and Gamble Co v Svenska Cellulosa Aktiebolaget SCA [2012] EWCA Civ 1413 at [22] and at [38], per Moore-Bick and Rix LJJ.

${ }^{231}$ [2015] UKSC 36; [2015] A.C. 1619 at [155], per Lord Carnwath.

232 [2015] UKSC 36; [2015] A.C. 1619 at [157], per Lord Carnwath: "the case seems to cry out for expert mediation".

233 [2015] UKSC 36; [2015] A.C. 1619 at [65], per Lord Neuberger, and [79], per Lord Hodge.

234 [2016] EWCA Civ 789 at [45], per Moore-Bick L.J.

235 Neil Andrews, Contract Law, 2nd ed. (Cambridge: Cambridge University Press, 2015), chapter 21 (and citing copious literature); see also Neil Andrews, Contract Rules: Decoding English Law (Cambridge: Intersentia Publishing, 2016), Article 5. 
to sue the hiring party for demurrage charges exceeding the value of the hired goods. ${ }^{236}$ For present purposes, the Court of Appeal's non-recognition of a general concept of "good faith" "in matters of contract" is notable because of Moore-Bick L.J.'s expression of concern that this concept could subvert the process of contractual interpretation: "There is in my view a real danger that if a general principle of good faith were established it would be invoked as often to undermine as to support the terms in which the parties have reached agreement. The danger is not dissimilar to that posed by too liberal an approach to construction, against which the Supreme Court warned in Arnold v Britton [2015] UKSC 36, [2015] A.C. 1619."'237

\section{Concluding Remarks}

The only interpretative endeavour (under English contract law) is objective ascertainment of the document's legal meaning. For this purpose, the reasonable reader (who must be commercially sensitive and astute) will consider everything which the law permits him to take into account, assessed at the time of formation. This objective search is illuminated by (a) the relevant background of the contract, to which both parties are deemed to be privy, including the commercial setting of the contract and (b) the parties' shared objective(s) under the transaction. But, necessarily, the objective construction cannot be contaminated by reference to the unilateral, particular, and subjective intentions of each party.

Commercial common sense is a versatile 238 element within the interpretative process: (1) it forms part of the overall framework within which the adjudicator construes the document; as such it is a member of an interpretative team of relevant factors which, sensitively applied, increase the chances of adjudication regularly yielding sound results; (2) CCS also operates as a "safety valve" criterion to guard against absurdity; (3) furthermore, whenever rival meanings genuinely emerge, even if absurdity is not in prospect, CCS comes into play as a potentially decisive factor.

The case law emphasises the need for a moderate and cautious use of commercial common sense, for the following reasons:

1. partisan arguments are often dressed up as issues of commercial common sense: judges should not be beguiled by forensic rhetoric which is a barely disguised plea for a favourable revision or gloss to suit one party but which is not truly supported by the document;

2. judges should not pretend to greater commercial or trade or "street" experience than they in fact possess;

\footnotetext{
236 [2015] EWHC 283 (Comm); [2015] 2 All E.R. (Comm.) 614; [2015] 1 Lloyd's Rep. 359 at [97], [98].

${ }^{237}$ For other cautious comments, Beatson L.J. in Globe Motors Inc v TRW Lucas Varity Electric Steering Ltd [2016] EWCA Civ 396; [2017] 1 All E.R. (Comm) 601 at [68].

${ }^{238}$ E.g., Starlight Shipping Co v Allianz Marine \& Aviation Versicherungs AG [2014] EWHC 3068 (Comm); [2015] 2 All E.R. (Comm.) 747; [2014] 2 Lloyd's Rep. 579 at [51], per Flaux J. ("literalism" and construction which "defies business sense"), at [52] ("absurdity" and congruence with "business common sense"), at [53] and [54] (promotion of the "clear objective intention" of a settlement agreement).
} 
3. textual fidelity should be maintained: commercial common sense should not become a promiscuous pretext for rewriting the text in the name of abstract "improvement" of the contract; nor is it a red pen to be used to reconstruct a better contract in favour of one party, thereby saving that party from hardship;

4. courts are alive to the chance that a transaction's odd, curious or tough wording is the result of compromise or even deliberate obfuscation; because English courts cannot lift the lid on the negotiations, this possibility must act as a powerful constraint against over-confident rewriting of contracts in the name of "commercial common sense". 